\title{
Modelling the impact of forest loss on shallow landslide sediment yield, Ijuez river catchment, Spanish Pyrenees
}

\author{
James C. Bathurst ${ }^{1}$, Greta Moretti ${ }^{2}$, Ahmed El-Hames ${ }^{3}$, Santiago Beguería ${ }^{4}$ and \\ Jose M. García-Ruiz ${ }^{5}$
}

\author{
${ }^{1}$ Water Resource Systems Research Laboratory, School of Civil Engineering and Geosciences, University of Newcastle upon Tyne, Newcastle upon Tyne, NE1 7RU, UK \\ ${ }^{2}$ Ingenieurbüro Winkler und Partner GmbH, Schloßstr. 59A, 70176 Stuttgart, Germany \\ ${ }^{3}$ Department of Hydrology and Water Resource Management, King Abdulaziz University, PO Box 80208, Jeddah 21589, Saudi Arabia \\ ${ }^{4}$ Division Landscape Dynamics, GIS and Hydrology, Faculty of Geosciences, Utrecht University, PO Box 80115, 3508TC Utrecht, The Netherlands \\ ${ }^{5}$ Instituto Pirenaico de Ecología, CSIC, Campus de Aula Dei, Apartado 202, 50080- Zaragoza, Spain
}

Email for corresponding author: j.c.bathurst@ncl.ac.uk

\begin{abstract}
The SHETRAN model for simulating the sediment yield arising from shallow landslides at the scale of a river catchment was applied to the 45- $\mathrm{km}^{2}$ Ijuez catchment in the central Spanish Pyrenees, to investigate the effect of loss of forest cover on landslide and debris flow incidence and on catchment sediment yield. The application demonstrated how such a model, with a large number of parameters to be evaluated, can be used even when directly measured data are not available: rainfall and discharge time series were generated by reference to other local records and data providing the basis for a soil map were obtained by a short field campaign. Uncertainty bounds for the outputs were determined as a function of the uncertainty in the values of key model parameters. For a four-year period and for the existing forested state of the catchment, a good ability to simulate the observed long term spatial distribution of debris flows (represented by a 45 -year inventory) and to determine catchment sediment yield within the range of regional observations was demonstrated. The lower uncertainty bound on simulated landslide occurrence approximated the observed annual rate of landsliding and suggests that landslides provide a relatively minor proportion of the total sediment yield, at least in drier years. A scenario simulation in which the forest cover was replaced by grassland indicated an increase in landsliding but a decrease in the number of landslides which evolve into debris flows and, at least for drier years, a reduction in sediment delivery to the channel network.
\end{abstract}

Keywords: catchment model, DAMOCLES, forest impact, land-use impact, model calibration, sediment yield, landslide, SHETRAN

\section{Introduction}

Loss of forest cover is a major environmental concern worldwide. Anthropogenic pressures are the principal causes of such loss, although natural causes (e.g. fire) may have locally significant effects. On steeper lands, loss of tree cover may allow increased soil erosion, by surface runoff, gullying and landsliding, and a consequent increase in sediment delivery to the river system and in basin sediment yield. Undesirable impacts may then include siltation of aquatic habitat, aggradation of river beds (with consequences for flooding) and reservoir sedimentation. It would be helpful, therefore, to have a means of predicting erosion and the resulting impact on downstream sediment yield as a function of forest cover. Mathematical modelling offers the prospect of exploring the extent of, and integrating, knowledge of the relevant processes and links and as a means of quantifying the impacts. However, the availability of such models, and demonstrations of their capability, is still limited. In particular, most erosion models consider only erosion by raindrop impact and overland flow. Gully and landslide erosion are rarely quantified. Therefore, to help broaden the available modelling experience, this paper presents an application of the SHETRAN model for shallow landslide sediment yield to determine sediment yield for the $45-\mathrm{km}^{2}$ Ijuez upland river catchment in the central Spanish Pyrenees, for its current largely forested state and for a scenario condition in which the forest cover has been removed. As well as modelling the impact of forest cover 
on soil erosion, the application was concerned with demonstrating an ability to provide improved estimates of basin scale sediment yield, in support of more efficient landuse planning and engineering design. The principal aims of the paper are:

- to show how a landslide sediment yield model can be used to examine the effect of a change of forest cover on shallow landslide and debris flow incidence and on sediment yield at the catchment scale;

- to show how a physically based, spatially distributed model can be used even in the absence of directly measured field data.

The application was carried out as part of the European Commission (EC)-funded DAMOCLES project (Bathurst et al., 2003; http://www.damocles.irpi.cnr.it).

\section{Impact of forest cover on landslide and debris flow incidence}

It is well established that forests on sloping ground protect against landslide erosion through their root-binding action and (because of their relatively high transpiration and interception rates) by increasing soil moisture deficits (i.e. creating drier soils), which allow reduced soil pore water pressures (e.g. Greenway, 1987). Removal of forest cover is likely to result in increased slope instability (e.g. Amaranthus et al., 1985; Sidle et al., 1985; Guthrie, 2002; Dhakal and Sidle, 2003; Keim and Skaugset, 2003). The protection has been found to remain effective at extreme rainfalls (Phillips et al., 1990), at least for mature forests. However, when landslides do occur on forested slopes, in extreme rainfall and wind events such as hurricanes, they may be larger and more destructive than on unforested slopes. In particular, they are likely to evolve into debris flows which deliver large volumes of sediment and woody debris to the channel network (e.g. Eschner and Patrick, 1982; DeGraff et al., 1989, Fig. 20). There is also some evidence that the average volume of landslides in forest areas exceeds those in clearcut areas or grassland, at least for the larger slides (Amaranthus at al., 1985; Reneau and Dietrich, 1987). The larger volumes and more destructive nature of landslides in forested areas may be explained by the greater root binding action. For land under grass cover, root binding is relatively weak and landslide occurrence is more closely controlled by the soil cohesion. The initial area in which cohesion is overcome is likely to be relatively small and the landslide scar is therefore similarly limited. Under forest cover, though, slope failure depends more on the root strength and occurs at conditions considerably in excess of those which would be needed simply to overcome soil cohesion. By the time failure does occur, therefore, the soil has entered an unstable condition over a relatively extensive area. Consequently failure involves both more energy and a greater area of instability.

The ability to model the effect of vegetation cover on slope stability at the scale of a hillslope using geotechnical analysis is well demonstrated in the literature (e.g. Wilkinson et al., 2002; Keim and Skaugset, 2003). The extension of such analysis to the small catchment scale (up to a few square kilometres) has been demonstrated by, among others, Montgomery and Dietrich (1994) and Wu and Sidle (1995), while more recently catchment scale models have been applied to investigate the effect of forestry activities on landslide hazard (Dhakal and Sidle, 2003; Vanacker et al., 2003). Takahashi and Nakagawa (1989) developed a model for landslide sediment yield which they tested at a basin scale of around 20 ha. However, as far as the authors are aware, SHETRAN is the only physically based model which provides an ability to model both landslide occurrence and the resulting sediment yield at catchment scales relevant to a range of engineering interests (up to $500 \mathrm{~km}^{2}$ ).

\section{SHETRAN shallow landslide model}

\section{MODEL BACKGROUND}

The SHETRAN landslide sediment yield model is a development of the original SHE (Système Hydrologique Européen) hydrological modelling system, which was built in a collaborative programme by the then Institute of Hydrology (now the Centre for Ecology and Hydrology, Wallingford), the then Danish Hydraulic Institute (now DHI Water \& Environment) and SOGREAH (Abbott et al., 1986a, b). Following the transfer of the UK SHE programme to the University of Newcastle upon Tyne, a component for modelling soil erosion by raindrop impact and overland flow was added (Bathurst et al., 1995; Wicks and Bathurst, 1996). Subsequently the resulting model was heavily revised to produce SHETRAN, a general, physically based, spatially distributed modelling system that can be used to construct and run models of all or any part of the land phase of the hydrological cycle (including sediment and contaminant transport) (Ewen et al., 2000).

Through its integrated surface and subsurface representation of river basins, SHETRAN provides soil moisture conditions and thence a basis for simulating rainand snowmelt-triggered landsliding. The SHETRAN landslide component was thus developed to simulate the erosion and sediment yield associated with shallow landslides at the basin scale (Burton and Bathurst, 1998). The occurrence of shallow landslides is determined as a 
function of the time- and space-varying soil saturation conditions simulated by SHETRAN, using standard, geotechnical, infinite-slope, factor-of-safety analysis. This includes allowance for the effect of vegetation root cohesion. For each landslide the volume of eroded material is determined from the soil depth and the area of the landslide. Using a rule-based approach, and in line with the above review of debris flow occurrence, the eroded material is routed down the hillslope as a debris flow if the vegetation is forest or if the landslide occurs in a gully. However, if the landslide occurs on a planar grass-covered slope, there is no onward transport. The model has an option to allow the debris flow to collect additional sediment by scouring along its track (not considered necessary for the Ijuez simulation). Deposition by the debris flow occurs once the gradient falls below a certain critical value (initially set at $10^{\circ}$ ) and takes place over the run-out distance, which is calculated as a percentage of the difference in elevation between the landslide location and the critical slope. (Initially this proportion was set at $40 \%$.) The proportion of the material reaching the channel network is then calculated and fed to the SHETRAN sediment transport component for routing to the basin outlet. Material deposited along the track of the debris flow may subsequently be washed into the channel by overland flow.

Within SHETRAN, the spatial distribution of catchment properties, rainfall input and hydrological response is achieved in the horizontal direction through the representation of the catchment and its channel system by an orthogonal grid network and in the vertical direction by a column of horizontal layers at each grid square. However, grid resolution is typically large (as much as 1 or $2 \mathrm{~km}$ ) compared with the length dimensions of shallow landslides (typically around 10-100 m). The central feature of the landslide model, therefore, is the use of derived relationships (based on a topographic index) to link the SHETRAN grid resolution at which the basin hydrology and sediment yield are modelled, to a subgrid resolution at which landslide occurrence and erosion is modelled. That is, using the topographic index, the SHETRAN grid saturated zone thickness is distributed spatially at the subgrid resolution. If the factor-of-safety analysis indicates slope failure at a subgrid element, that element counts as one landslide. Through this dual resolution design, the model is able to represent landsliding at a physically realistic scale while remaining applicable at basin scales (up to $500 \mathrm{~km}^{2}$ ) likely to be of interest, for example feeding a reservoir. The subgrid discretisation, landslide susceptibility and potential landslide impact (e.g. sediment delivered to the stream system) are determined in advance using a Geographical Information System and this information is stored in a 'look-up' table.
During the time-varying simulation SHETRAN provides information on the temporal variation in soil moisture content as input to the landslide model. As landslides occur, their predetermined sediment impacts are passed to the SHETRAN sediment transport component from the lookup table and the sediment is routed along the channel system to the basin outlet.

The ability of the basic SHETRAN flow and sediment transport model to simulate the impact of forest cover on soil erosion and sediment yield has been demonstrated by Lukey et al. (2000). A first test of the landslide model, showing an ability to simulate the spatial distribution of landslides and the catchment sediment yield within quantified uncertainty bounds for the $505-\mathrm{km}^{2}$ upper Llobregat catchment in the south-eastern Spanish Pyrenees, is reported by Bathurst et al. (2006). Subsequent application of the landslide model to scenarios for future climate and land use for the $180-\mathrm{km}^{2}$ Valsassina catchment in the Italian Southern Alps is presented by Bathurst et al. (2005). This paper follows on from the Valsassina application to investigate the impact of deforestation on shallow landslide incidence and sediment yield for the Ijuez catchment.

Full details of the equations and data needs of SHETRAN and its landslide sediment yield component have been reported in a number of publications (Burton and Bathurst, 1998; Ewen et al., 2000; Bathurst et al., 2005) and are therefore not repeated here. The version of the model used for the Ijuez application is the same as that described in Bathurst et al. (2005).

\section{MODEL UNCERTAINTY}

Two particular sources of uncertainty are taken into account. The first arises from the uncertainty in parameterising physically based, spatially distributed models (Beven and Binley, 1992; Beven, 2001, pp.19-23; Guimarães et al., 2003). This is accounted for by setting bound values on the more important model parameters and, through simulation, creating corresponding bounds on the model output (Ewen and Parkin, 1996; Lukey et al., 2000; Bathurst et al., 2004). The aim of the landslide modelling then becomes that of bracketing the observed pattern of occurrence with several simulations based on the different parameter bound values, rather than reproducing the observed pattern as accurately as possible with one simulation (Bathurst et al., 2006).

The second area of uncertainty arises from the impracticality of measuring the required landslide model parameters (for the factor-of-safety equation) at every model subgrid element across the entire catchment and the consequent reliance on estimated values. A certain proportion of elements is then characterised with unrealistic 
combinations of parameter values and is simulated to be unconditionally unstable, even in dry conditions. Before simulating the period of interest, these instabilities need to be eliminated so that only sites with physically realistic combinations of parameter values are retained. Bathurst et al. (2006) tested an approach in which a preceding simulation involving a relevant rainfall time series (e.g. based on past extreme events) was used to identify and thus exclude the unwanted landslides. This was a pragmatic approach, considered useful when simulating large events. However, it also introduced an element of calibration, since the rainfall time series was selected to provide the best agreement between the simulated and observed landslide patterns. Bathurst et al. (2005) therefore investigated an alternative approach, in which all the landslides that occurred at the start of the simulation (e.g. in the first 24 hours) before there was any rain, were eliminated. This approach was also used in the case of the Ijuez application.

\section{The Ijuez catchment}

The $45-\mathrm{km}^{2}$ Ijuez catchment was selected as a test area because it lies in the calcareous flysch sector of the central Spanish Pyrenees, which was the focus for regional hazard assessment modelling in the DAMOCLES project (Lorente et al., 2002, 2003). A particular reason for selecting the catchment was that, at the time, it contained 60-100 debris flow sites. The Ijuez is a tributary of the Aragón river, $10 \mathrm{~km}$ from the city of Jaca (Fig. 1). Elevations in the catchment range from 838 to $2173 \mathrm{~m}$, the main lithology is calcareous flysch and the natural vegetation is mainly pines, shrubs and, in the highest parts, meadows. In former times the catchment was heavily farmed, causing considerable erosion, including landslides and debris flows. Part of the catchment was therefore reforested in 1955-56. The main stream flows all year, fed by groundwater and soil water, but the smaller streams dry up in the summer. There can be some snowmelt in the spring months. Tributary streams flow in steep-sided narrow valleys. Landslides and debris flows are evident at various locations in the catchment. There is also significant evidence of erosion and sediment transport along the stream system, in the form of channel bars, bank collapse, braiding and substantial check dams built in the past to stabilise the channel.

North facing slopes tend to have deeper soils with a higher organic content: the plantation trees have grown more and there are fewer landslides. As a result of the past farming, the soils on the south facing slopes are thinner, have a poor organic content and are very stony. Tree growth on the southfacing slopes is poorer and there are more landslides.

The simulation was intended to be representative of recent conditions and the period 1/1/95-31/12/98 was therefore selected. The period happened to be relatively dry, with 1998 the driest year.

Mean annual rainfall at Jaca is $874 \mathrm{~mm}$. Regionally, the peak runoff period is spring with a secondary peak in autumn (García-Ruiz et al., 2001).

\section{Data collection and analysis}

The data required by SHETRAN are:

(i) Precipitation and potential evaporation input data to drive the simulation, preferably at hourly intervals;

(ii) Topographic, soil, vegetation, sediment and geotechnical properties to characterise the catchment

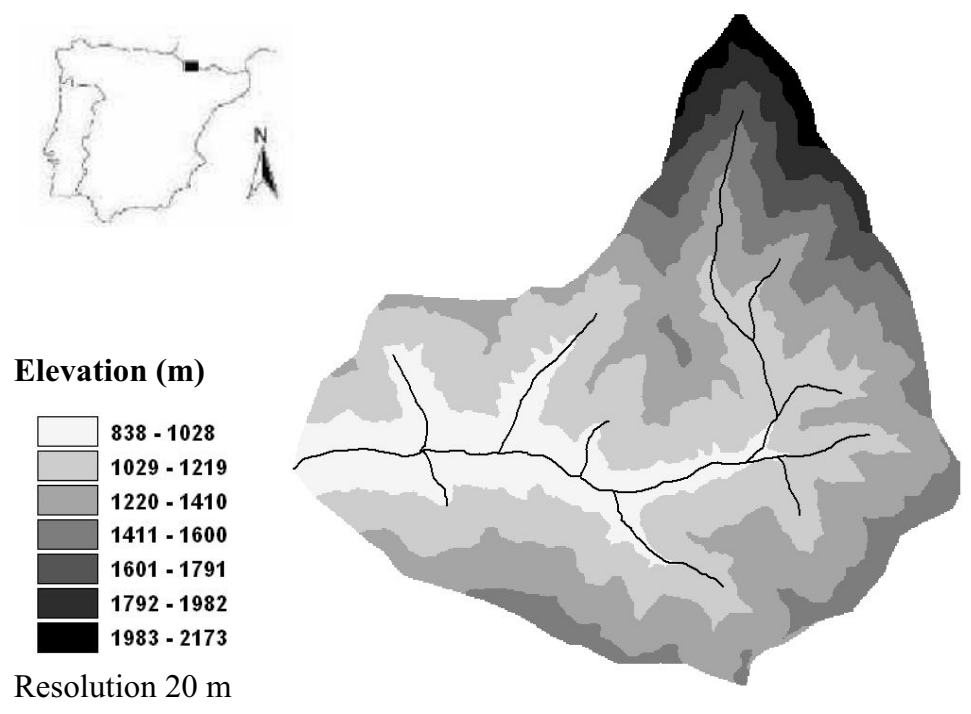

Fig. 1. Ijuez catchment map (showing elevation and channel network) and location map. 
on a spatially distributed basis;

(iii) Discharge records, sediment yield and a landslide inventory, for testing the model output.

As is typically the case in applications to all but the most densely instrumented catchments, some of these data were readily available, others had to be collected in the field and all required conversion into the SHETRAN format. The paper illustrates how the necessary data can be compiled even in the absence of direct measurements.

\section{PRECIPITATION}

Daily precipitation records were available for one station in the catchment (Bescos, with data from 1970 onwards) and four others around the catchment. However, most of them contain significant gaps during the 1990s. Hourly precipitation data were available only at Jaca (from 1989 onwards), $10 \mathrm{~km}$ away from the catchment. Because of a gap in the Bescos record for 1995-97, it was first necessary to generate the Bescos daily record for this period by correlation with the Jaca record for other years (a relationship was derived with $\mathrm{r}^{2}=0.73$ for a 13 -year period). Thus for the simulation period, only the 1998 data come directly from the Bescos record. A relationship between daily total precipitation and hourly duration was then established for Jaca. This was then used to disaggregate the Bescos daily record to the hourly scale with a University of Newcastle statistically based code called Raindist (C. G. Kilsby, personal communication).

Data for the region show an altitude dependency in annual rainfall. The Ijuez catchment was therefore divided into three rainfall bands according to altitude $(800-1200 \mathrm{~m}$, 1200-1600 m and over $1600 \mathrm{~m}$ ). Each area has different hourly rainfall values calculated from the Bescos disaggregated precipitation data and based on the annual total precipitation versus elevation relationship.

Frontal rainfall is normal during November to May, so if it rains at Jaca it is likely also to rain at Bescos. During the summer season rainfall is convective and not spatially uniform, so the correlation between the Jaca and Bescos record is then likely to be poorer.

\section{EVAPOTRANSPIRATION}

Pan evaporation data are available at Bescos for certain years and for the summer months only. Potential evapotranspiration values were therefore derived from the mean daily temperature record (average of maximum and minimum) at Bescos using the Blaney-Criddle formula (e.g. Dunne and Leopold, 1978, p139):

$$
P E=p(0.46 T+8.13)
$$

where $P E=$ daily potential evapotranspiration $\left(\mathrm{mm} \mathrm{day}^{-1}\right)$, $p=$ percentage of the annual hours of daylight each day, expressed as a mean daily value for each month (\%) (data from Shaw (1994)) and $T=$ mean daily temperature $\left({ }^{\circ} \mathrm{C}\right)$. The Bescos temperature record was available for 1971 to 1994, excluding 1990, and from 1998 to 1999. The derivation was first carried out for 1991 and 1998, as there were pan data for those years, so that the Blaney-Criddle equation could be calibrated. The calibrated equation was then applied to generate daily evapotranspiration (assumed constant in each day) for 1995-1998, using the 1998 temperature data for each year. Actual evapotranspiration was calculated in the simulations from a relationship between the ratio of actual to potential evapotranspiration and soil water potential (Denmead and Shaw, 1962). The ratio was set to a maximum value for saturated conditions, decreasing to zero at the wilting point. Compared with rainfall, evaporation shows relatively little interannual variability and the approximations inherent in the above procedure are not thought to be a major source of error.

\section{TOPOGRAPHY AND MODEL GRID}

A 10-m resolution Digital Elevation Model (DEM) provided by the Instituto Pirenaico de Ecología, Consejo Superior de Investigaciones Cientificas, (CSIC-IPE) formed the basis of the SHETRAN topographic model. The SHETRAN grid resolution (used for the hydrological and sediment transport component) was chosen to be $500 \mathrm{~m}$, giving 189 squares. A 20-m DEM resolution was selected as the subgrid resolution of the landslide model. The river network was generated from the 10-m DEM: 70 river links were thus defined, where a river link is equal to one side of a SHETRAN grid square. The model grid and channel network are shown in Fig. 2.

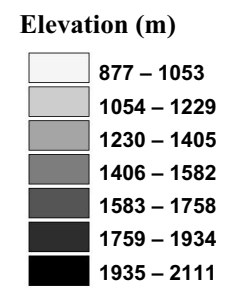

Resolution $500 \mathrm{~m}$

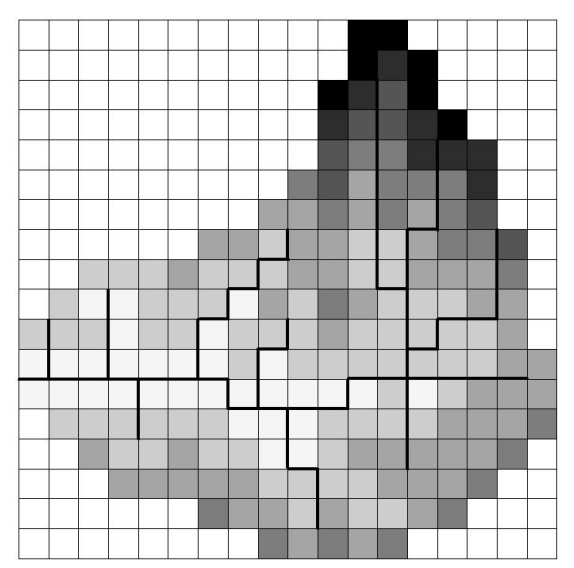

Fig. 2. SHETRAN grid network, channel system and elevation distribution for the Ijuez catchment. 
At $47.25 \mathrm{~km}^{2}$, the SHETRAN model area is slightly larger than the actual area of the Ijuez catchment $\left(45 \mathrm{~km}^{2}\right)$. The landslide model area was $46 \mathrm{~km}^{2}$.

\section{SOIL PROPERTIES AND SOIL MAP}

A three-day field visit was made in June 2001 to collect soil samples as a basis for determining the model soil parameters (principally for the factor-of-safety equation). Twelve samples were collected from across the catchment. The field measurements, sample collection methodology and laboratory analysis to give the hydraulic and geotechnical properties were the same as described in Bathurst et al. (2005) and are not repeated here.

From the field observations and the laboratory analysis it was concluded that the soil does not vary significantly in the Ijuez catchment. However, two main soil types (silty clay and silty clay loam) were noted, with slight differences in the physical and mechanical characteristics. No soil map was available and a means was therefore sought to extrapolate from the point samples to a catchment scale distribution through correlation with catchment characteristics which could affect soil type and distribution. Correlations of particle size distribution and of effective angle of internal friction with topography and vegetation cover were explored. (No geology map was available for the Ijuez catchment to explore correlation with geology.) No relationship was found with topography but it was

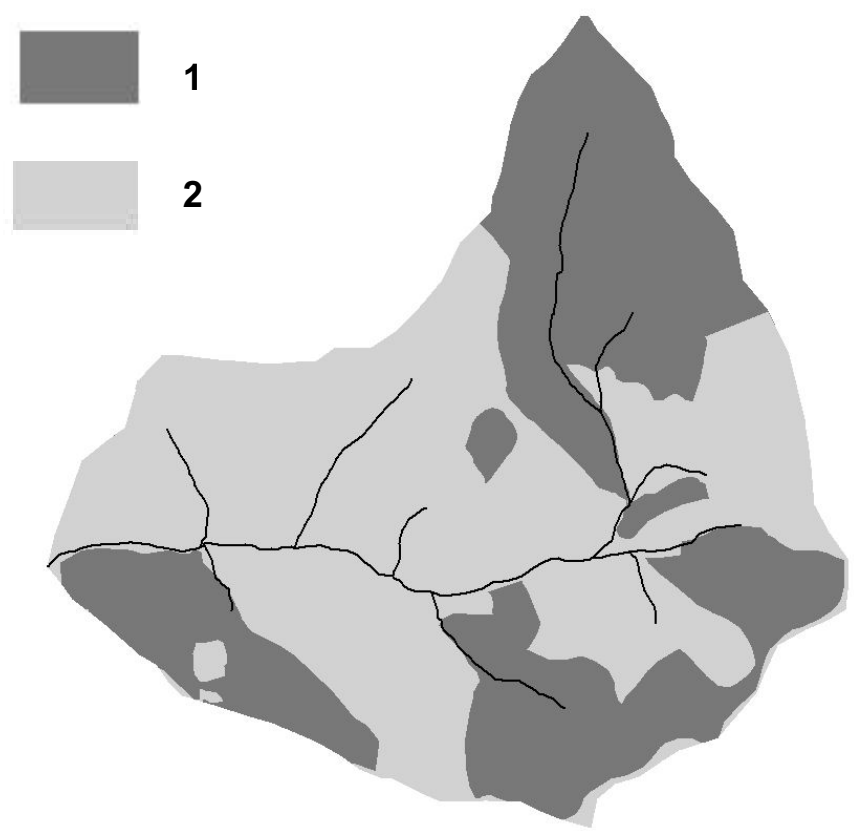

Fig. 3. The soil map created for the Ijuez catchment. Details of the two soil types are shown in Table 1. noticed that soil type 1 tended to occur in areas covered with natural forest while soil type 2 tended to occur in the reforested areas. Although the correlation was not exact, it was considered to be the best that could be achieved with the available data and to be appropriate for use in a modelling exercise aimed at the catchment scale, rather than a detailed local scale. Therefore, using the vegetation map as a basis, a soil map showing the distribution of the two soil types identified above was created (Fig. 3).

Mean values of the SHETRAN soil parameters for the two soil types are shown in Table 1.

\section{VEGETATION COVER}

A vegetation map was provided by the Instituto Geológico y Minero de España (Zaragoza) (partners in the DAMOCLES project) and showed seven main vegetation types: meadows, beeches, farmed areas, oaks, pines, shrubs and reforested pines. Partly as a result of observations made during the field visit, these seven classifications were reduced to three for the simulations: beeches, oaks and pines (the beeches and oaks cover only a small area and combining them with pines was therefore considered reasonable); meadows, farmed areas and shrubs; and reforested pines. The resulting vegetation map is shown in Fig. 4. The vegetation property data required for the SHETRAN hydrological and sediment transport simulations were obtained from the literature and past experience in model applications (e.g. Lukey et al., 2000). For the landslide model, root cohesion was varied as part of the procedure

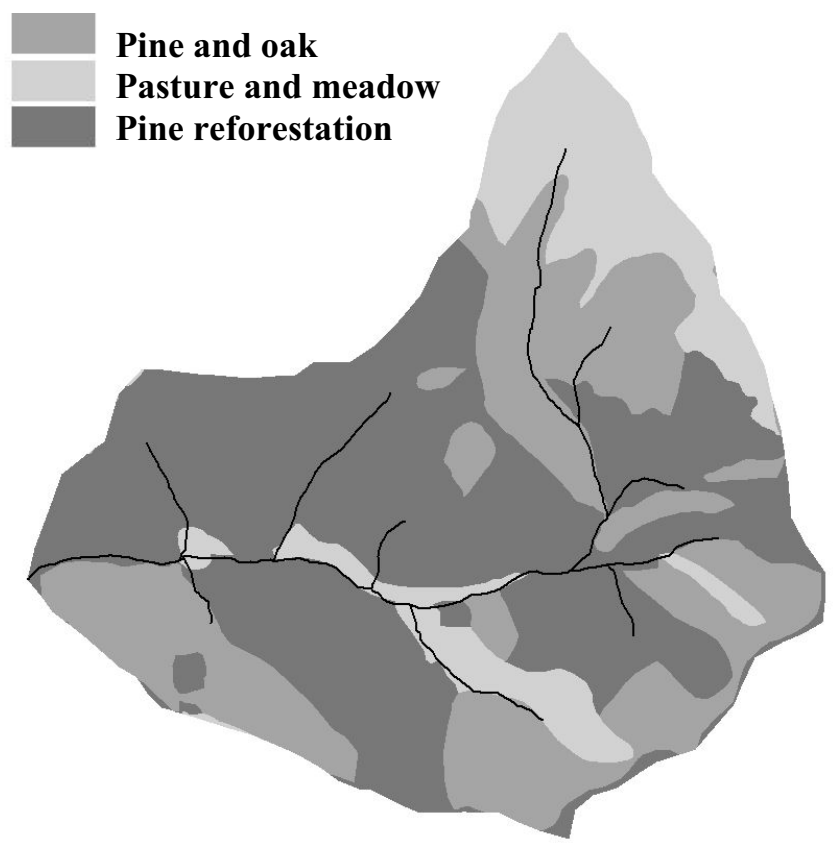

Fig. 4. The vegetation cover map created for the Ijuez catchment. 
Modelling the impact of forest loss on shallow landslide sediment yield, ljuez river catchment, Spanish Pyrenees

Table 1. SHETRAN soil parameters for the two soil types used to characterise the Ijuez catchment

\begin{tabular}{|c|c|c|c|c|c|c|c|c|c|c|c|c|c|c|c|}
\hline \multirow[t]{2}{*}{$\begin{array}{l}\text { Soil } \\
\text { class }\end{array}$} & \multicolumn{3}{|c|}{ Percentage of Sand } & \multicolumn{3}{|c|}{$\begin{array}{l}\text { Saturated Water Content } \\
\qquad\left(\mathrm{m}^{3} \mathrm{~m}^{-3}\right)\end{array}$} & \multicolumn{3}{|c|}{$\begin{array}{l}\text { Residual Water Content } \\
\qquad\left(\mathrm{m}^{3} \mathrm{~m}^{-3}\right)\end{array}$} & \multicolumn{3}{|c|}{$\begin{array}{l}\text { Water Content at Field } \\
\text { Capacity }\left(\mathrm{m}^{3} \mathrm{~m}^{-3}\right)\end{array}$} & \multicolumn{3}{|c|}{$\begin{array}{c}\text { Water Content at Wilting } \\
\text { Point }\left(\mathrm{m}^{3} \mathrm{~m}^{-3}\right)\end{array}$} \\
\hline & $\begin{array}{l}\text { lower } \\
\text { limit }\end{array}$ & $\begin{array}{l}\text { upper } \\
\text { limit }\end{array}$ & average & $\begin{array}{l}\text { lower } \\
\text { limit }\end{array}$ & $\begin{array}{l}\text { upper } \\
\text { limit }\end{array}$ & average & $\begin{array}{l}\text { lower } \\
\text { limit }\end{array}$ & $\begin{array}{l}\text { upper } \\
\text { limit }\end{array}$ & average & $\begin{array}{l}\text { lower } \\
\text { limit }\end{array}$ & $\begin{array}{l}\text { upper } \\
\text { limit }\end{array}$ & average & $\begin{array}{l}\text { lower } \\
\text { limit }\end{array}$ & $\begin{array}{l}\text { upper } \\
\text { limit }\end{array}$ & average \\
\hline 1 & 1.92 & 16.5 & 9.22 & 0.515 & 0.541 & 0.528 & 0.141 & 0.172 & 0.157 & 0.352 & 0.430 & 0.391 & 0.186 & 0.265 & 0.226 \\
\hline 2 & 2.42 & 12.4 & 7.41 & 0.493 & 0.520 & 0.506 & 0.092 & 0.133 & 0.112 & 0.307 & 0.358 & 0.333 & 0.125 & 0.182 & 0.154 \\
\hline \multirow[t]{2}{*}{$\begin{array}{l}\text { Soil } \\
\text { class }\end{array}$} & \multicolumn{3}{|c|}{$\begin{array}{l}\text { Saturated Conductivity } \\
\qquad\left(m d a y^{-1}\right)\end{array}$} & \multicolumn{3}{|c|}{ van Genuchten alpha } & \multicolumn{3}{|c|}{ van Genuchten n } & \multicolumn{3}{|c|}{$\begin{array}{l}\text { Weight Density of Saturated } \\
\text { Soil }\left(\mathrm{N} / \mathrm{m}^{3}\right)\end{array}$} & \multicolumn{3}{|c|}{$\begin{array}{c}\text { Weight Density of Soil at Field } \\
\text { Moisture Content }\left(\mathrm{N} / \mathrm{m}^{3}\right)\end{array}$} \\
\hline & $\begin{array}{l}\text { lower } \\
\text { limit }\end{array}$ & $\begin{array}{l}\text { upper } \\
\text { limit }\end{array}$ & average & $\begin{array}{l}\text { lower } \\
\text { limit }\end{array}$ & $\begin{array}{l}\text { upper } \\
\text { limit }\end{array}$ & average & $\begin{array}{l}\text { lower } \\
\text { limit }\end{array}$ & $\begin{array}{l}\text { upper } \\
\text { limit }\end{array}$ & average & $\begin{array}{l}\text { lower } \\
\text { limit }\end{array}$ & $\begin{array}{l}\text { upper } \\
\text { limit }\end{array}$ & average & $\begin{array}{l}\text { lower } \\
\text { limit }\end{array}$ & $\begin{array}{l}\text { upper } \\
\text { limit }\end{array}$ & average \\
\hline 1 & 0.076 & 0.103 & 0.089 & $\begin{array}{c}6.63 \times \\
10^{-3}\end{array}$ & $\begin{array}{c}8.12 \times \\
10^{-3}\end{array}$ & $\begin{array}{c}7.37 \times \\
10^{-3}\end{array}$ & 1.31 & 1.44 & 1.37 & 17840 & 23860 & 20850 & 16400 & 22590 & 19490 \\
\hline 2 & 0.121 & 0.274 & 0.198 & $\begin{array}{c}7.53 \times \\
10^{-3}\end{array}$ & $\begin{array}{c}7.97 \times \\
10^{-3}\end{array}$ & $\begin{array}{c}7.75 \times \\
10^{-3}\end{array}$ & 1.43 & 1.50 & 1.47 & 17580 & 22030 & 19810 & 15930 & 20440 & 18180 \\
\hline
\end{tabular}

Note: Soil moisture conditions in the unsaturated zone are modelled using the van Genuchten $(1980)$ equation, $\mathrm{S}=\left(\theta-\theta_{\mathrm{r}}\right) /\left(\theta_{\mathrm{s}}-\theta_{\mathrm{r}}\right)=$

$\left[1+(-\alpha h)^{\mathrm{n}}\right]^{-\mathrm{w}}$, where $\mathrm{S}=$ degree of saturation (dimensionless fraction), $\mathrm{q}=$ volumetric moisture content $\left(\mathrm{m}^{3} \mathrm{~m}^{-3}\right), \mathrm{q}_{\mathrm{s}}=$ saturated volumetric moisture content $\left(\mathrm{m}^{3} \mathrm{~m}^{-3}\right), \mathrm{h}=$ pressure head $(\mathrm{m}), \mathrm{n}, \alpha\left(\mathrm{m}^{-1}\right)$ and $\mathrm{q}_{\mathrm{r}}$ (residual water content) are fitted empirical constants and $\mathrm{W}=1-(1 /$ n).

for defining the model uncertainty envelope but was based on literature data such as Sidle et al. (1985), Preston and Crozier (1999) and Abernethy and Rutherfurd (2001). Vegetative surcharge was assumed to be negligible.

\section{DISCHARGE}

There was no discharge record for the Ijuez river which could be used to test the simulation results. A discharge record was therefore obtained by scaling the Aragón river record at Jaca, using a regionally based scaling equation. To establish the equation, discharge records were collected from a number of gauging stations in the area. Relationships between annual total discharge and catchment area as well as between monthly mean discharge and area were derived using data from 34 catchments ranging in size from $40 \mathrm{~km}^{2}$ to more than $2000 \mathrm{~km}^{2}$. These equations effectively determined the Ijuez discharge as 0.19 times the Aragón discharge at the monthly scale and this factor was applied to scale the mean daily discharge records for the Aragón.

\section{LANDSLIDE INVENTORY}

An inventory map of debris flow occurrence in the Ijuez catchment for the period from 1956 to 2001 was available for testing the landslide simulations. The map was compiled by the CSIC-IPE from the interpretation of a historical series of aerial photographs and from field surveys. For the period 1956-2001, 146 debris flows were identified, 21 of which occurred during 1990-2001. Analysis shows a nearly steady rate of occurrence through the period, despite variations in land use and rainfall. (In fact, there has been a slight decrease from 3.6 landslides per year during 1957-1977 to 2.4 during 1977-2002 (Beguería, 2005).) It is therefore suggested that the triggering of shallow landslides and the subsequent formation of debris flows in the Ijuez catchment is related to relatively frequent intense rainfalls with recurrence intervals of no more than 2 to 5 years (Lorente et al., 2003). As noted earlier, there is a greater preponderance of debris flows on the south-facing slopes. There is also a general absence of debris flows on the meadow lands above the tree line at the north end of the catchment.

Analysis of debris flow characteristics in the flysch sector quantified the mean value of the critical slope below which debris flow deposition occurs as $18^{\circ}$ and the run-out distance as $60 \%$ of the difference in elevation between the landslide location and the critical slope (Lorente et al., 2003). These values therefore replaced the SHETRAN default values of $10^{\circ}$ and $40 \%$ (Burton and Bathurst, 1998).

\section{SEDIMENT YIELD}

There were no sediment yield records for the Ijuez catchment which could be used to test the simulation results. More indirect data were therefore used, consisting of measurements from elsewhere in the Spanish Pyrenees. Regional long term yields of $1.5-4 \mathrm{t} \mathrm{ha}^{-1} \mathrm{yr}^{-1}$ are reported 
for catchments of 190 to $2694 \mathrm{~km}^{2}$ along the Central Pyrenees (Ebro valley) by Avendaño Salas et al. (1997). CSIC-IPE scientists have also measured yields of 2.04 and $1.87 \mathrm{t} \mathrm{ha}^{-1} \mathrm{yr}^{-1}$ on two small catchments $\left(2.84\right.$ and $0.95 \mathrm{~km}^{2}$ respectively) in the flysch area near the Ijuez catchment, for a period of one year (1/10/99-30/9/00). The first of these (4 km from the Ijuez catchment) refers to a largely deforested area and $73 \%$ of its total yield is composed of suspended (particulate) load. The second $(8.5 \mathrm{~km}$ from the Ijuez catchment) refers to a forested area and $73 \%$ of its total yield is composed of solute load (García-Ruiz et al., 2004). These figures may provide a general range for the expected order of magnitude of the Ijuez catchment yield.

\section{Model calibration and results}

\section{PROCEDURE}

As noted earlier, there is uncertainty in evaluating the model parameters and other inputs. The aim of the calibration was therefore not to reproduce the observed hydrological response and the observed occurrence of landslides as accurately as possible with one simulation but to bracket the observed responses with several simulations. Among them, these simulations should represent the uncertainty in the key inputs. Similarly, the event sediment yield should be represented by an uncertainty envelope rather than a single simulation.

The modelling and calibration procedure leading to the final event sediment yield involved the following sequential steps.

(i) Simulation of the hydrological response, to give the soil saturation and water flow data which form the input to the other components. Test against scaled Aragón river record.

(ii) Simulation of the sediment supply to the channel network, derived (a) from landslides and (b) from soil erosion by raindrop impact and overland flow. Comparison of the landslide simulations with the observed inventory.

(iii) Simulation of the sediment transport along the channel to the catchment outlet, to give the sediment yield. Test against regional data.

For stages (i) and (ii), the simulation uncertainty was quantified as a function of uncertainty in key model parameters by setting upper and lower bounds on the parameter values (Ewen and Parkin, 1996). For stage (iii) the overall maximum and minimum estimates of sediment yield should ideally be determined by carrying out simulations for each combination of the individual hydrological, landslide and soil erosion uncertainty runs. However, the required computing was not possible within the constraints of the study and the final hydrological input was represented by a single simulation (the baseline run, described in the following section).

The full test period was 1/1/95-31/12/98. It was preceded by the last six months of 1998 run as a 'settling down' period to allow the effect of the initial conditions to dissipate and to allow consistency to develop between the individual grid square conditions. The settling down period does not contribute to the final simulation results.

\section{Hydrology calibration}

In calibrating the hydrology model, adjustments were made to several of the parameters to which the results are most sensitive. These were the Strickler resistance coefficient for the overland flow, the ratio of actual to potential evapotranspiration at soil field capacity, the Van Genuchten exponent $n$ for the soil moisture content/tension curve (see Table 1) and the soil saturated zone hydraulic conductivity. (See Ewen et al. (2000) and Lukey et al. (2000) for a detailed explanation of these terms and their evaluation.) In particular, it was necessary to increase the soil saturated zone hydraulic conductivity to the relatively large value of $10 \mathrm{~m} \mathrm{day}^{-1}$ to simulate discharges with the appropriate magnitude and flow duration characteristics. This is large compared with the values of $0.09-2 \mathrm{~m}$ day $^{-1}$ derived from the measured soil particle size distribution using the formulation of Saxton et. al. (1986) (Table 1). The value of $10 \mathrm{~m} \mathrm{day}^{-1}$ may therefore be an effective value, representative at the model grid scale and the steep gradients in the Ijuez catchment (e.g. Bathurst and O'Connell, 1992). The resulting baseline values of the key parameters are shown in Table 2. These are the best estimates of the parameter values and the basis for setting the bound values accounting for uncertainty, which are also shown in the table. Based on observations in the catchment, soil depth was set at $1.5 \mathrm{~m}$. This depth, in the model, is considered to represent the unconfined aquifer lying above an impermeable layer.

To allow for covariance of the parameters, simulations were carried out for the eight different combinations of bound values (for the Strickler coefficient, the evapotranspiration ratio and the Van Genuchten exponent, Table 2), thereby producing an uncertainty envelope for the model output.

As the Ijuez/Aragón discharge scaling was based on monthly runoff data, comparison of the simulated and observed (i.e. scaled) Ijuez discharge time series is most 
Table 2. Baseline and bound values for the principal SHETRAN parameters for the Ijuez simulations

\begin{tabular}{llll}
\hline Parameter & $\begin{array}{l}\text { Baseline } \\
\text { value }\end{array}$ & Bound values \\
& upper lower \\
\hline
\end{tabular}

Strickler overland flow resistance coefficient:

$\begin{array}{llll}\text { pine (natural) } & 0.5 & 1 & 0.1 \\ \text { pine (planted) } & 0.5 & 1 & 0.1 \\ \text { shrubs/meadows } & 1 & 5 & 0.5\end{array}$

Actual/potential evapotranspiration ratio at soil field capacity

$\begin{array}{llll}\text { pine (natural) } & 0.5 & 0.8 & 0.3 \\ \text { pine (planted) } & 0.5 & 0.8 & 0.3 \\ \text { shrubs/meadows } & 0.3 & 0.5 & 0.2\end{array}$

Van Genuchten coefficient for soil moisture content/tension curve:

$\begin{array}{llll}\text { soil } 1 & 1.37 & 1.5 & 1.3 \\ \text { soil } 2 & 1.47 & 1.6 & 1.4\end{array}$

\begin{tabular}{llll} 
Soil depth $(\mathrm{m})$ & 1.5 & 1.5 & 1.5 \\
$\begin{array}{l}\text { Saturated zone conductivity } \\
\left(\mathrm{m} \mathrm{day}^{-1}\right)\end{array}$ & 10 & 10 & 10 \\
$\begin{array}{l}\text { Soil erodibility coefficients: } \\
\quad \text { raindrop impact }\left(\mathrm{J}^{-1}\right)\end{array}$ & - & 0.2 & 0.05 \\
$\quad$ overland flow $\left(\mathrm{mg} \mathrm{m}^{-2} \mathrm{~s}^{-1}\right)$ & - & 2 & 0.5 \\
Root cohesion $(\mathrm{Pa})$ : & & & \\
$\quad$ Natural pine & - & 1500 & 700 \\
$\quad$ Plantation pine & - & 800 & 300 \\
$\quad$ Shrubs/meadows & - & 800 & 300 \\
\hline
\end{tabular}

appropriate at the monthly scale. Figure 5 shows this comparison for the baseline simulation. The discrepancies in the first half of each year can be explained by a snowmelt contribution to the Aragón flows which would not in reality have appeared in the Ijuez flows. Similarly, the high simulated discharges for December 1995 and January 1996 are considered realistic: this was a relatively wet period compared with the same periods in the other years, giving high runoff. The much more subdued response for the scaled Aragón flows could be due to the precipitation falling as snow and being stored on the ground at the higher elevations of that catchment. There are more minor differences in August 1996 and July 1997 which are unexplained. Otherwise the simulated flow magnitudes and month-tomonth variations are realistic. The simulated runoff/rainfall coefficient is 0.48 .

Figure 6 compares the simulated and measured (i.e. scaled) daily flow duration curves. For the purposes of the comparison, the discharges are normalised with respect to the mean annual discharge. As should be expected, the figure shows the Ijuez to have a more flashy regime than that represented by the Aragón, even allowing for the uncertainty. The scaled Aragón discharges may therefore not represent well the event-scale response of the Ijuez. The figure also shows the Aragón to be less flashy in the mid-1990s than in the longer term, suggestive of more subdued flows in the drier conditions of that time.

From the above, the differences between the simulated and observed (i.e. scaled) discharges can be explained in physical terms. The hydrology model is therefore considered to be representative of the Ijuez catchment for the purposes

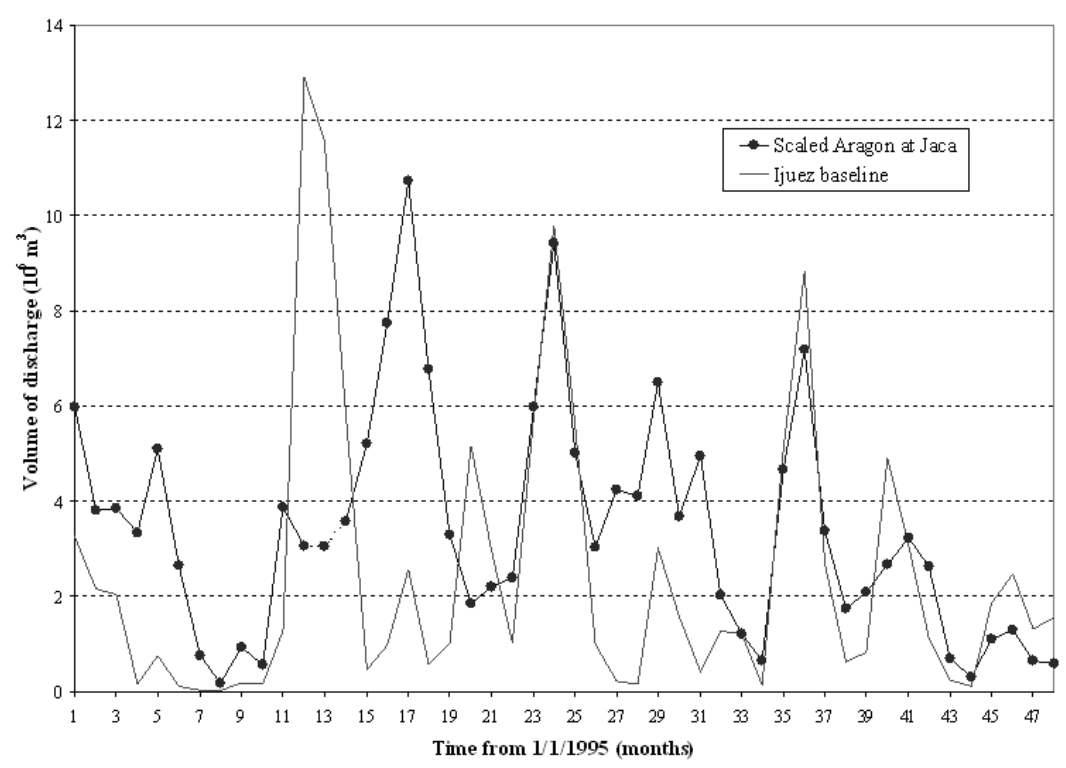

Fig. 5. Comparison of the simulated baseline monthly discharge volume for the Ijuez outlet with the scaled values for the Aragón river at Jaca for the period $1 / 1 / 95-31 / 12 / 98$. 


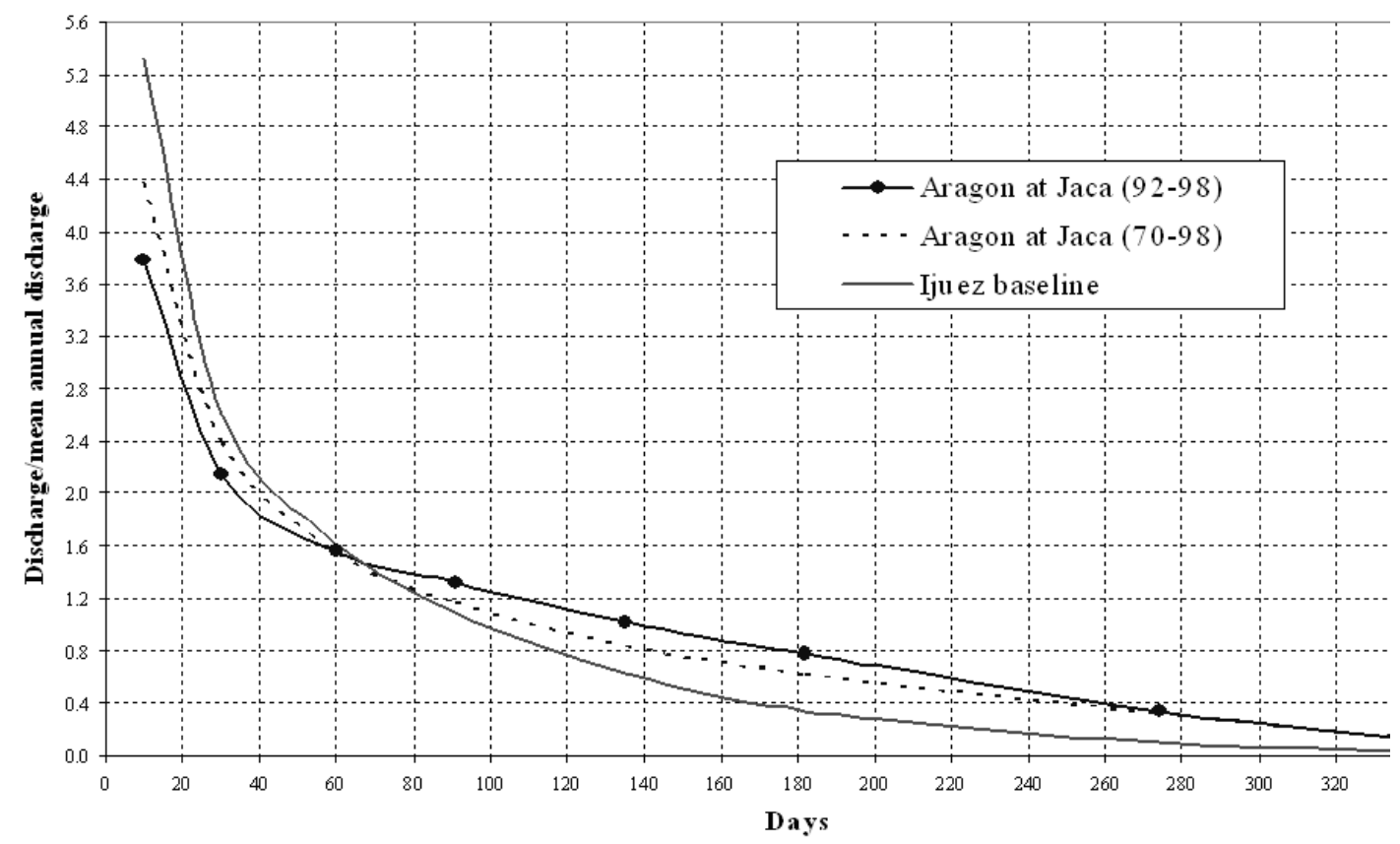

Fig. 6. Comparison of the normalized flow duration curve for the scaled Aragón discharge record at Jaca with the simulated baseline curve for the Ijuez outlet. The Aragón curve is shown both for the long term period of record and for the dry period of the mid 1990s.

of the landslide modelling.

\section{Landslide calibration}

The simulation does not cover the full period represented by the landslide inventory map. Consequently the principal aim of the validation was to reproduce not the number of landslides but the general spatial distribution of landslide occurrence. However, the observed incidence for 1990-2001 also provided a rough basis for testing the bounds on the simulated incidence for 1995-1998. As the observations refer to debris flows whereas the model determines landslides, it was necessary to distinguish in the simulation between those landslides which evolve into debris flows and those which do not.

The procedure was similar to that reported in earlier applications (Bathurst et al., 2005, 2006). Hydrological input was provided by the baseline flow simulation and bounds on the landslide simulation were obtained by setting bounds on the root cohesion (Table 2). It was found that smaller bound values were needed, compared with simulations for other catchments (Bathurst et al., 2005), otherwise no landslides were simulated. The smaller values are justified by the poorer purchase afforded the roots by the thin soil and flysch structure. The other soil parameters were evaluated as, for soils 1 and 2: soil cohesion 4.42 and 4.13 $\mathrm{kPa}$; angle of friction $29.8^{\circ}$ and $29.7^{\circ}$. Depth to the shear surface was set at $0.85 \mathrm{~m}$. Landslides were precluded from occurring at slopes less than $25^{\circ}$ and more than $50^{\circ}$, in good general agreement with the survey of Lorente et al. (2002) which showed most debris flows to be on $20-35^{\circ}$ gradients. Landslides which occurred in the first 24 hours of the simulation were eliminated as indicating squares defined as unconditionally unsafe.

It can be seen that there is a difference between the SHETRAN grid soil depth of $1.5 \mathrm{~m}$ (the depth of the unconfined aquifer) and the landslide model subgrid soil depth of $0.85 \mathrm{~m}$ (the depth to the shear surface). This arises from calibration requirements and approximations in the model parameterisation. When such cases occur, however, the model design ensures that soil moisture is conserved between the two scales.

Figure 7 compares the 50-year map of observed debris flows with the upper and lower simulated bounds for 1995 1998. Considering in particular the upper simulated bound, reproduction of the observed spatial distribution is good. The apparent discrepancy between the low observed incidence and high simulated incidence in the high meadow area at the north of the catchment is explained as follows. The simulations refer to landslides: according to SHETRAN's rule-based approach, these may evolve into debris flows on forested slopes but not on grassy slopes such as the meadows. The observations, however, refer to debris flows. García-Ruiz et al. (1990) report that landslips do occur on the high meadows but these do not form debris flows and do not transfer much sediment into the river system. Hence simulation and observation are in general 

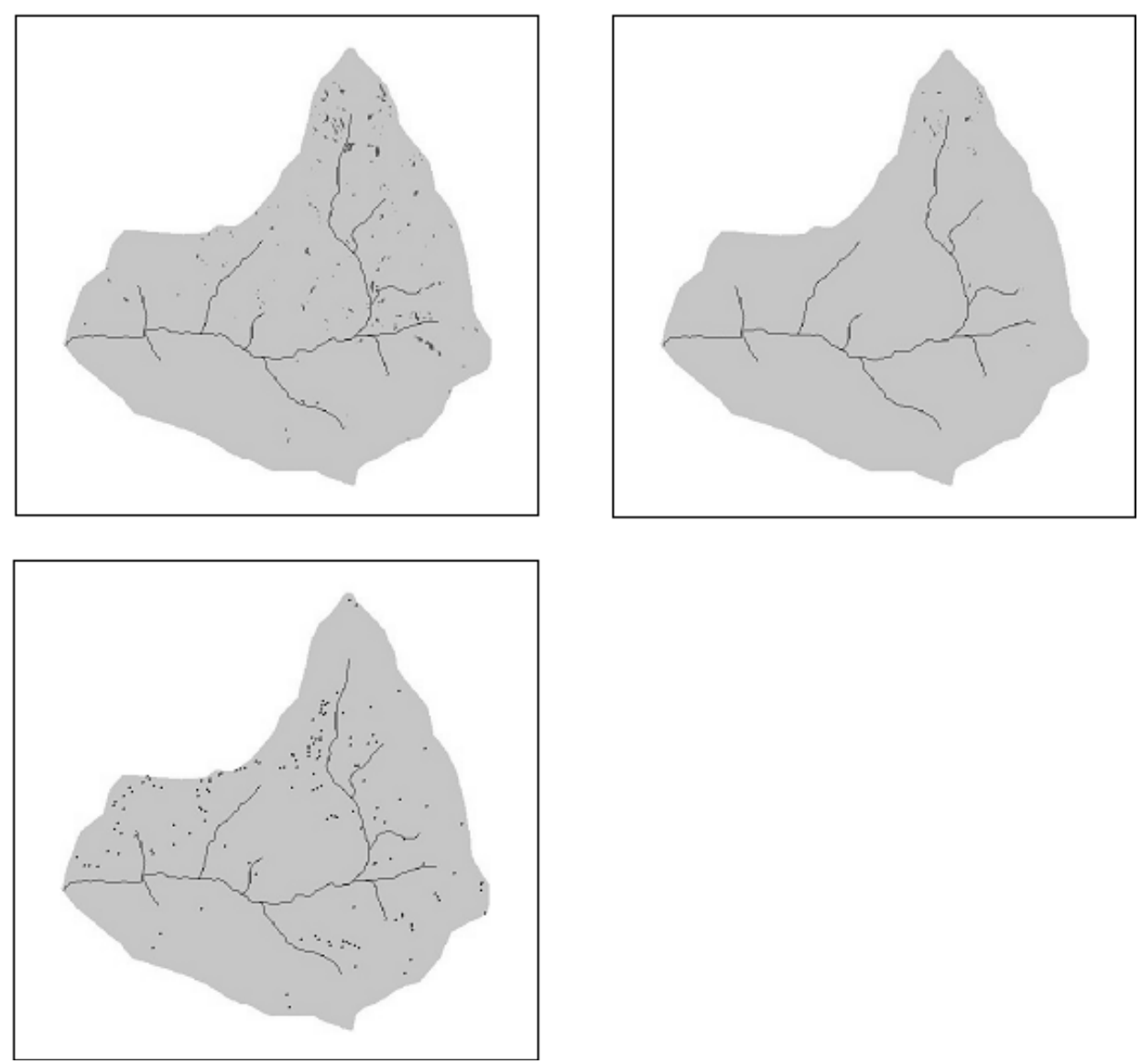

Fig. 7. Comparison of uncertainty bounds for the SHETRAN landslide simulation (upper diagrams) with the 1956-2001 map of observed debris flows (lower diagram) in the Ijuez catchment. Landslide and debris flow locations are shown as dots.

agreement for the high meadows in terms of debris flow occurrence.

For the long term period represented by the debris flow inventory (146 debris flows during 1956-2001), the annual rate of debris flow occurrence is about 3. During 19902001, 21 debris flows were recorded, giving a slightly lower rate of occurrence of about 2 . The reduction may be explained by the relatively low rainfalls of the 1990s compared with the long term average and by the use of field recognition mapping in the 2001 debris flow survey, which can be less exhaustive than the aerial photographic analysis used in the earlier surveys. The reforestation of the 1950s may also have had a stabilising effect, although Beguería (2005) shows that, even after 50 years, this effect is not equivalent to that of a well established forest. The bounds on the number of simulated landslides for 1995-1998 are 96 and 857. For the lower bound the number is made up mainly of landslides on the high meadows: very few landslides are simulated in the lower catchment. All the landslides are simulated to occur in 1995, corresponding to the higher rainfall of that year compared with the others.
The corresponding bounds for the number of landslides which evolve into debris flows are 12 and 462 (generally not in meadows or grasslands), giving annual rates of debris flow occurrence of 3 to 115 . This suggests that the lower simulation bound may be generally representative of reality. As with previous applications, the upper simulation bound is a considerable overestimate of the observed number but is helpful in defining the spatial distribution of landslides.

The landslide model may be predisposed to provide a slight overestimate of the number of landslides owing to the way in which the landsides are counted. The number is calculated as the number of subgrid elements in which a slope failure is simulated. If there are failures in two neighbouring elements, they are counted as two separate slides, whereas in reality they may have been one.

On the basis of these results, the landslide model is considered to be representative of the Ijuez catchment. However, the lower bound on landsliding (with the upper bounds on root cohesion) is likely to be rather closer to the observed incidence than is the upper bound. Similar findings were obtained for the applications to Valsassina and the 
Llobregat catchment (Bathurst et al., 2005, 2006).

\section{Sediment yield calibration}

For the simulations, uncertainty bounds were set on the soil erodibility coefficients, which indicate the ease with which the soil can be eroded by raindrop impact and by overland flow (see Wicks and Bathurst, 1996, for a description of the coefficients) (Table 2), while hydrological input was provided by the baseline run. The proportion of ground protected from raindrops or raindrip erosion by vegetation or other cover was set at 0.7 for all vegetations. Without the contribution from debris flows, the sediment yield simulated for $1995-98$ was $0.67 \mathrm{t} \mathrm{ha}^{-1} \mathrm{yr}^{-1}$, there being no sensitivity to the erodibility coefficients. The experience of CSIC-IPE scientists is that there needs to be very wet weather over several days for the whole catchment to contribute to sediment yield. As the 1990s were relatively dry it is thought that there was little overland flow and therefore little sediment yield from the hillslopes. The lack of overland flow may explain the insensitivity of the simulation results to the soil erodibility coefficients. Sediment sources in the catchment tend instead to be close to the river network (with the addition of debris flow inputs from the hillslopes). Adding the lower and upper bounds for debris flow contribution to the simulated yield raises the yield to 0.77 and $2.08 \mathrm{t} \mathrm{ha}^{-1} \mathrm{yr}^{-1}$ respectively. These values are very similar to those observed in the flysch area (around $2 \mathrm{t} \mathrm{ha}^{-1} \mathrm{yr}^{-1}$ ) (García-Ruiz et al., 2004). On this basis the sediment yield model is considered to be representative of the Ijuez catchment.

Noting that the lower bound on the number of simulated landslides is likely to be more realistic than the upper bound, the same is likely to be true for the simulated sediment yield. This suggests that the supply of material derived from shallow landslides to the main channel is relatively minor compared with the supply from channel and other hillslope sources $\left(0.1 \mathrm{tha}^{-1} \mathrm{yr}^{-1}\right.$ out of a total of $\left.0.77 \mathrm{t} \mathrm{ha}^{-1} \mathrm{yr}^{-1}\right)$. The material simulated to come from landslides is likely to be a mix of material brought from the hillslopes by debris flows on forested land and material deposited directly into the river system from landslides immediately adjacent to the channel (especially in the grassland area).

\section{Scenario simulations}

Once the full model had been tested for the current conditions, it was used to explore the sensitivity of the landslide sediment supply system to removal of the forest cover. As above, the hydrological response is simulated for the baseline conditions, modified to account for the landuse change as appropriate, while the landslide and sediment yield simulations incorporate uncertainty based respectively on root cohesion and soil erodibility coefficients.

The most realistic land-use change for the Ijuez catchment is loss of the tree cover by fire. The catchment was therefore modelled with a complete grass and pasture cover, representing the catchment a few years after a fire but before the re-establishment of larger vegetation such as shrubs and, eventually, trees. In this condition, the tree roots are assumed to have decayed (a condition which typically sees landslide occurrence increase several years after tree removal, e.g. Amaranthus et al., 1985; Sidle et al., 1985). It is assumed that the soil has resumed its normal properties and that any hydrophobic effects induced by the fire (e.g. Sidle et al., 1985; Varela et al., 2005) have disappeared. It is further assumed that potential evapotranspiration, as determined with the Blaney-Criddle equation calibrated by pan evaporation data, remains the same as with the current land use. However, the maximum value of the ratio of actual to potential evapotranspiration was decreased in line with the data in Table 2 .

According to the model results, conversion of the catchment to a full grass cover provokes an increase in landslide occurrence (Table 3). However, by the rule-based conditions in SHETRAN, none of the landslides can develop into a debris flow, i.e. the number of debris flows is zero. Therefore, the only contribution to sediment yield can come from landslides directly adjacent to the channel system or

Table 3. Results for the SHETRAN Ijuez simulations

\begin{tabular}{|c|c|c|c|c|c|c|c|}
\hline \multirow[t]{3}{*}{ Scenario } & \multirow{3}{*}{$\begin{array}{l}\text { Mean annual } \\
\text { rainfall } \\
\mathrm{mm}\end{array}$} & \multirow{3}{*}{$\begin{array}{l}\text { Mean annual } \\
\text { pot. evapo- } \\
\text { transpiration } \\
\text { mm }\end{array}$} & \multirow{3}{*}{$\begin{array}{l}\text { Simulated mean } \\
\text { annual runoff } \\
\mathrm{mm}\end{array}$} & \multicolumn{3}{|c|}{ Simulated sediment yield } & \multirow{3}{*}{$\begin{array}{l}\text { Simulated } \\
\text { number of } \\
\text { landslides }\end{array}$} \\
\hline & & & & $\begin{array}{l}\text { without } \\
\text { landslides }\end{array}$ & $\begin{array}{l}\text { from land- } \\
\text { slides only }\end{array}$ & $\begin{array}{l}\text { total with } \\
\text { landslides }\end{array}$ & \\
\hline & & & & $t h a^{-1} y r^{-1}$ & $t h a^{-1} y r^{-1}$ & $t h a^{-1} y r^{-1}$ & \\
\hline Current vegetation & 1241 & 950 & 757 & 0.67 & $0.10-1.41$ & $0.77-2.08$ & $96-857$ \\
\hline Grassland & 1241 & 950 & 778 & 0.76 & $0.05-0.78$ & $0.81-1.54$ & $183-1089$ \\
\hline
\end{tabular}


from landslide material deposited on the hillslopes and washed into the channel by overland flow. Overall, the material contributed by landsliding is approximately halved, falling from the range of $0.1-1.41 \mathrm{tha}^{-1} \mathrm{yr}^{-1}$ to $0.05-0.78$ $\mathrm{t} \mathrm{ha}^{-1} \mathrm{yr}^{-1}$. There is a small increase in runoff associated with the lower transpiration and interception of the grassland compared with the forest and consequently a small increase in sediment yield derived from non-landslide sources. However, while this maintains the lower bound on total sediment yield $\left(0.81 \mathrm{t} \mathrm{ha}^{-1} \mathrm{yr}^{-1}\right.$ compared with $0.77 \mathrm{t} \mathrm{ha}^{-1}$ $\mathrm{yr}^{-1}$ for the forested case), the upper bound falls from 2.08 to $1.54 \mathrm{t} \mathrm{ha}^{-1} \mathrm{yr}^{-1}$.

The scenario results can all be explained by physical reasoning. In addition they match the analysis by Lorente et al. (2002) of debris flow occurrence in the flysch sector containing the Ijuez catchment. This analysis found the distribution of debris flows to be higher in reforested areas (31\%), shrublands (24\%) and areas with natural pine forest (20\%) compared with meadow lands (7\%). The noncultivated area contained $68 \%$ of all the debris flows compared with $30 \%$ in sloping fields. The results also match the general observation that the number of landslides increases after tree removal. On the other hand, they do not agree with observations that suggest an accompanying increase in sediment yield. A possible reason for this could be the absence of overland flow, which means that the increase in hillslope erosion (from landslides and because of reduced protection against raindrop impact) is not converted into an increased supply to the river system. Wetter conditions could produce a different result.

Given the uncertainties in the parameter evaluation, the relative variation between the simulations is likely to be more reliable than the simulated output magnitudes. Comparison of the scenario results with the simulation for the current period therefore provides an indication of the potential changes in catchment response and thus provides a context within which guidelines for land management can be developed to minimise debris flow impacts. In particular:

- assuming that the lower bounds on sediment yield are more realistic than the upper bounds, the supply of shallow landslide material to the channel contributes relatively little (about 13\%) to the overall catchment sediment yield;

- a decrease in the hillslope forest cover is likely to cause a significant increase (doubling) in landslide occurrence and a small increase in runoff. However, whether this translates into an increase in sediment yield is likely to depend on the rainfall pattern.

\section{Conclusions}

While the principal tree-related factors which influence landslide occurrence are well established, it is only recently that they have been represented in catchment scale models and the capability of such models, especially at scales larger than a few square kilometres, has not been demonstrated. The application of the SHETRAN landslide sediment yield model to the Ijuez catchment is intended to provide one such demonstration.

(i) The application demonstrates an ability to simulate the observed long term spatial distribution of debris flows and to determine catchment sediment yield within the range of observations from a wider region. However, the annual rate of landsliding may be estimated more accurately by the lower rather than the upper uncertainty bound. The result also suggests that landslides provide a relatively minor proportion of the total sediment yield, at least in drier years.

(ii) The scenario application investigated the effect of removal of forest cover on landslide and debris flow occurrence and sediment yield. Landslide incidence is simulated to increase but the number of landslides which evolve into debris flows is decreased. As a consequence, and given the relatively low rainfall and resulting lack of overland flow for the simulation period, there is a reduction in sediment delivery to the channel network. The relationship between landslide/debris flow occurrence and tree cover from the simulation generally matches observations from the local flysch sector and more general observations about the effect of forest logging.

(iii) The application has demonstrated how a physically based model, with large parameter evaluation requirements, can be used even when direct measurements are not available. In particular, the Bescos rainfall time series was generated with reference to other local rainfall records and extrapolated on an altitudinal basis, a discharge time series was generated by scaling from other local catchments and data providing the basis for a soil map were obtained by a short field campaign.

Some aspects of the model application need further consideration.

(i) Considering the particular application, the simulation period 1995-98 was relatively dry and it is therefore possible that the full capability of the model was not 
tested. In particular, the effect of overland flow in transporting both landslide material and soil eroded by raindrop impact does not seem to have been important in the test period. Wetter conditions could produce a different balance of outcomes.

(ii) As with the applications reported by Bathurst et al. (2005, 2006), there are aspects of the modelling approach which need further examination. These include: the most suitable method to eliminate the large number of unconditionally unsafe landslide squares predicted at the start of a simulation; how best to reduce the simulated upper bound on the number of landslides, which is typically a large overestimate of the observed occurrence; and the extent to which parameters other than root cohesion should be used in setting the bounds on landslide occurrence. While the three applications have established the feasibility of modelling landslide sediment yield at the catchment scale, greater refinement is needed for future applications.

\section{Acknowledgements}

This paper is part of a collection honouring the achievements of Professor McCulloch. As Director of the former Institute of Hydrology (now Centre for Ecology and Hydrology, Wallingford), he fostered major research developments in, among other topics, river catchment modelling (including the predecessor of SHETRAN) and the hydrological effects of forests. It is appropriate, therefore, that this paper can refer to both these themes.

The authors thank Adrian Lorente (Instituto Pirenaico de Ecología) for debris flow data and other information on the Ijuez catchment. They also thank the Diputación General de Aragón and the Instituto Geológico y Minero de España (Zaragoza) for their advice and for their interest in the simulation results. Chris Hunt (Technician, University of Newcastle upon Tyne) is thanked for his help and advice in the laboratory analysis of the soil samples. The DAMOCLES project was funded by the Environment and Sustainable Development Programme of the European Commission Research Directorate General, under Contract Number EVG1-CT-1999-00007, and this support is gratefully acknowledged.

\section{References}

Abbott, M.B., Bathurst, J.C., Cunge, J.A., O'Connell, P.E. and Rasmussen, J., 1986a. An introduction to the European Hydrological System - Système Hydrologique Européen, "SHE", 1: History and philosophy of a physically-based, distributed modelling system. J. Hydrol., 87, 45-59.
Abbott, M.B., Bathurst, J.C., Cunge, J.A., O'Connell, P.E. and Rasmussen, J., 1986b. An introduction to the European Hydrological System - Système Hydrologique Européen, "SHE", 2: Structure of a physically-based, distributed modelling system. J. Hydrol., 87, 61-77.

Abernethy, B. and Rutherfurd, I. D., 2001. The distribution and strength of riparian tree roots in relation to riverbank reinforcement. Hydrol. Process., 15, 63-79.

Amaranthus, M.P., Rice, R.M., Barr, N.R. and Ziemer, R.R., 1985. Logging and forest roads related to increased debris slides in southwestern Oregon. J. Forestry, 83, 229-233.

Avendaño Salas, C., Sanz Montero, E., Cobo Rayán, R. and Gómez Montaña, J.L., 1997. Sediment yield at Spanish reservoirs and its relationship with the drainage basin area. Proc. 19th Congress International Commission on Large Dams, Florence, Italy, Q.74R.54, 863-874.

Bathurst, J.C. and O'Connell, P.E., 1992. Future of distributed modelling : the Système Hydrologique Européen. Hydrol. Process., 6, 265-277.

Bathurst, J.C., Wicks, J.M. and O'Connell, P.E., 1995. The SHE/ SHESED basin scale water flow and sediment transport modelling system. In: Computer Models of Watershed Hydrology, V.P. Singh (Ed.), Water Resources Publications, Highlands Ranch, Co., USA. 563-594.

Bathurst, J.C., Crosta, G., García-Ruiz, J.M., Guzzetti, F., Lenzi, M. and Ríos, S., 2003. DAMOCLES: Debrisfall Assessment in Mountain Catchments for Local End-users. In: Debris Flow Hazards Mitigation: Mechanics, Prediction and Assessment, D. Rickenmann and C-L. Chen (Eds.), Millpress, Rotterdam, The Netherlands. 2, 1073-1083.

Bathurst, J.C., Ewen, J., Parkin, G., O'Connell, P.E. and Cooper, J.D., 2004. Validation of catchment models for predicting landuse and climate change impacts. 3. Blind validation for internal and outlet responses. J. Hydrol., 287, 74-94.

Bathurst, J.C., Moretti, G., El-Hames, A., Moaven-Hashemi, A. and Burton, A., 2005. Scenario modelling of basin-scale, shallow landslide sediment yield, Valsassina, Italian Southern Alps. Nat. Haz. Earth Syst. Sci., 5, 189-202.

Bathurst, J.C., Burton, A., Clarke, B.G. and Gallart, F., 2006. Application of SHETRAN basin-scale, landslide sediment yield model to Llobregat basin, Spanish Pyrenees. Hydrol. Process. In press.

Beguería, S., 2005. Changes in land cover and shallow landslide activity: A case study in the Spanish Pyrenees. Geomorphol., In press. (On-line copy in 2005.)

Beven, K.J., 2001. Rainfall-Runoff Modelling: The Primer.Wiley, Chichester, UK. 360pp.

Beven, K. and Binley, A., 1992. The future of distributed models: model calibration and uncertainty prediction. Hydrol. Process., 6, 279-298.

Burton, A. and Bathurst, J.C., 1998. Physically based modelling of shallow landslide sediment yield at a catchment scale. Environ. Geol., 35, 89-99.

DeGraff, J.V., Bryce, R., Jibson, R.W., Mora, S. and Rogers, C.T., 1989. Landslides: their extent and significance in the Caribbean. In: Landslides: Extent and Economic Significance, E.E. Brabb and B.L. Harrod (Eds.), Balkema, Rotterdam, The Netherlands, 68.

Denmead, O.T. and Shaw, R.H., 1962. Availability of soil water to plants as affected by soil moisture content and meteorological conditions. Agronomy J., 54, 385-390.

Dhakal, A.S. and Sidle, R.C., 2003. Long-term modelling of landslides for different forest management practices. Earth Surf. Process. Landf., 28, 853-868.

Dunne, T. and Leopold, L.B., 1978. Water in Environmental Planning. Freeman, San Francisco, USA. 818pp. 
Eschner, A.R. and Patrick, J.H., 1982. Debris avalanches in eastern upland forests. J. Forestry, 80, 343-347.

Ewen, J. and Parkin, G., 1996. Validation of catchment models for predicting land-use and climate change impacts. 1. Method. J. Hydrol., 175, 583-594.

Ewen, J., Parkin, G. and O'Connell, P.E., 2000. SHETRAN: distributed river basin flow and transport modeling system. $J$. Hydrologic Eng. - ASCE, 5, 250-258.

García-Ruiz, J.M., Alvera, B., Del Barrio, G. and Puigdefabregas, J., 1990. Geomorphic processes above timberline in the Spanish Pyrenees. Mountain Res. Devel., 10, 201-214.

García Ruiz, J.M., Beguería Portugués, S., López Moreno, J.I., Lorente Grima, A. and Seeger, M., 2001. Los Recursos Hidricos Superficiales del Pireneo Aragonés y su Evolución Reciente. Geoforma Ediciones, Logroño, Spain.

García-Ruiz, J.M., Lana-Renault, N., Beguería, S., Valero-Garces, B., Lasanta, T., Arnaez, J., Lopez-Moreno, J. I., Regues, D, and Marti-Bono, C., 2004. Temporal and spatial interactions of slope and catchment processes in the Central Spanish Pyrenees. IAHS Publication no. 288, 21-28.

Greenway, D.R., 1987. Vegetation and slope stability. In: Slope Stability, M.G. Anderson and K.S. Richards (Eds.), Wiley, Chichester, UK. 187-230.

Guimarães, R.F., Montgomery, D.R., Greenberg, H.M., Fernandes, N.F., Gomes, R.A.T. and de Carvalho Júnior, O.A., 2003. Parameterization of soil properties for a model of topographic controls on shallow landsliding: application to Rio de Janeiro. Eng. Geol., 69, 99-108.

Guthrie, R.H., 2002. The effects of logging on frequency and distribution of landslides in three watersheds on Vancouver Island, British Columbia. Geomorphol., 4, 273-292.

Keim, R.F. and Skaugset, A.E., 2003. Modelling effects of forest canopies on slope stability. Hydrol. Process., 17, 1457-1467.

Lorente, A., García-Ruiz, J.M., Beguería, S. and Arnáez, J., 2002. Factors explaining the spatial distribution of hillslope debris flows. Mountain Res. Devel., 22, 32-39.

Lorente, A., Beguería, S., Bathurst, J. C., and García-Ruiz, J. M., 2003. Debris flow characteristics and relationships in the Central Spanish Pyrenees. Nat. Haz. Earth Syst. Sci., 3, 683-692.

Lukey, B.T., Sheffield, J., Bathurst, J.C., Hiley, R.A. and Mathys, N., 2000. Test of the SHETRAN technology for modelling the impact of reforestation on badlands runoff and sediment yield at Draix, France. J. Hydrol., 235, 44-62.

Montgomery, D.R. and Dietrich, W.E., 1994. A physically based model for the topographic control on shallow landsliding. Water Resour. Res., 30, 1153-1171.
Phillips, C., Marden, M. and Pearce, A., 1990. Effectiveness of reforestation in prevention and control of landsliding during large cyclonic storms. Proc. $19^{\text {th }}$ Intl. Union Forest Res. Organizations World Congress, Montreal, Canada.

Preston, N.J. and Crozier, M.J., 1999. Resistance to shallow landslide failure through root-derived cohesion in east coast hill country soils, North Island, New Zealand. Earth Surf. Process. Landf., 24, 665-675.

Reneau, S.L. and Dietrich, W.E., 1987. Size and location of colluvial landslides in a steep forested landscape. IAHS Publication no. 165, 39-48.

Saxton, K.E., Rawls, W.J., Romberger, J.S. and Paperdick, R.I., 1986. Estimating generalized soil-water characteristics from texture. Soil Sci. Soc. Amer. J., 50, 1031-1036.

Shaw, E.M., 1994. Hydrology in Practice, $3^{\text {rd }}$ edn. Chapman and Hall, London, UK.

Sidle, R.C., Pearce, A.J. and O'Loughlin, C.L., 1985. Hillslope stability and land use. Water Resources Monograph Series 11, American Geophysical Union, Washington DC, USA.

Takahashi, T. and Nakagawa, H., 1989. Prediction of the sediment yield from a small basin in case of heavy rainfall. Annuals of the Disaster Prevention Research Institute, Kyoto University, No. 32 B-2, 689-707. (In Japanese)

Vanacker, V., Vanderschaeghe, M., Govers, G., Willems, E., Poesen, J., Deckers, J. and De Bievre, B., 2003. Linking hydrological, infinite slope stability and land-use change models through GIS for assessing the impact of deforestation on slope stability in high Andean watersheds. Geomorphol., 52, 299315.

Van Genuchten, M.Th., 1980. A closed form equation for predicting the hydraulic conductivity of unsaturated soils. Soil Sci. Soc. Amer. J., 44, 892-898.

Varela, M.E., Benito, E., and de Blas, E., 2005. Impact of wildfires on surface water repellency in soils of northwest Spain. Hydrol. Process., 19, 3649-3657.

Wicks, J.M. and Bathurst, J.C., 1996. SHESED: A physicallybased, distributed erosion and sediment yield component for the SHE hydrological modelling system. J. Hydrol., 175, 213238.

Wilkinson, P.L., Anderson, M.G. and Lloyd, D.M., 2002. An integrated hydrological model for slope stability. Earth Surf. Process. Landf., 27, 1267-1283.

Wu, W. and Sidle, R.C., 1995. A distributed slope stability model for steep forested basins. Water Resour. Res., 31, 2097-2110. 